\title{
Triiodothyronine (T3) Does not Induce Rankl Expression in Rat ROS 17/2.8 Cells
}

\begin{abstract}
Osteoclastogenesis may be regulated via activation of the RANK/RANKL (receptor activator of nuclear factor-kappa B/ receptor activator of nuclear factorkappa $B$ ligand) system, which is mediated by osteoblasts. However, the bone loss mechanism induced by T3 (triiodothyronine) is still controversial. In this study, osteoblastic lineage rat cells (ROS $17 / 2.8)$ were treated with T3 $\left(10^{-8} \mathrm{M}\right.$, $10^{-9} \mathrm{M}$, and $10^{-10} \mathrm{M}$ ), and RANKL mRNA (messenger RNA) expression was measured by semiquantitative RT-PCR. Our results show that T3 concentrations used did not significantly enhance RANKL expression compared to controls without hormone treatment. This data suggests that other mechanisms, unrelated to the RANK/RANKL system, might be to activate osteoclast differentiation in these cells. (Arq Bras Endocrinol Metab 2008;52/1:109-113)
\end{abstract}

Keywords: Thyroid hormone, RANKL, Bone, Rat, ROS17/2.8 cell

\section{RESUMO}

Triiodotironina (T3) não induz a expressão de Rankl em células de rato ROS 17/2.8.

A osteoclastogênese pode ser regulada via ativação do sistema RANK/RANKL (receptor ativador do fator nuclear kapa B/ ligante do receptor do fator nuclear kapa B), que é mediado pelos osteoblastos. Entretanto, o mecanismo de perda óssea induzido pelo T3 (triiodotironina) ainda é controverso. Neste estudo, a linhagem osteoblástica de células de rato ROS 17/2.8 foi tratada com T3 $\left(10^{-8} \mathrm{M}, 10^{-9} \mathrm{M}\right.$ e $\left.10^{-10} \mathrm{M}\right)$, e a expressão do mRNA do RANKL foi medida por RT-PCR semiquantitativo. Nossos resultados mostraram que as concentrações de T3 utilizadas não induziram significativamente a expressão do RANKL, comparado ao controle (sem tratamento hormonal). Estes dados sugerem que outros mecanismos, não relacionados ao sistema RANK/RANKL, são usados para ativar a diferenciação osteoclástica nestas células. (Arq Bras Endocrinol Metab 2008;52/1:109-113)

Descritores: Hormônio tireoidiano, RANKL, Osso, Rato, Células ROS 17/2.8

\section{INTRODUCTION}

B ONE RESORPTION BY OSTEOCLASTS and bone formation by osteoblasts are regulated by a variety of cytokines (IL-1, IL-4, IL-6, IL-11 und IFN-gamma) and growth factors (IGF-I, TGF- $\beta$ ) (1). Interaction of these factors in "basic multicellular units" acting locally on bone surfaces is thought to result in tight coupling of bone formation and resorption in bone-remodelling processes (2).

In vivo receptor activator of nuclear factor-kappa B ligand (RANKL) is essential for osteoclastogenesis reg+ulation and its signaling pathway media- artigo original

\author{
Patrícia P. Saraiva \\ SILVANIA S. TEIXEIRA \\ Célia Regina Nogueira \\ Carlos Roberto Padovani
}

Department of Medical Clinical of Botucatu School of Medicine, Sao Paulo State University (Unesp), Botucatu, SP, Brasil (PPS, SST, CRN); Department of Biostatistics of Botucatu School of Medicine, Sao Paulo State University (Unesp), Botucatu, SP, Brasil (CRP)

Recebido em 06/07/2007 Aceito em 01/10/2007 
tes humoral signs that regulate bone resorption and calcium metabolism (3).

The balance of two peptides produced by stromal osteoblasts, osteoprotegerin (OPG) and RANKL is critical in the bone resorption process. RANKL stimulates osteoclast differentiation through its receptor RANK (receptor activator of nuclear factor-kappa B) (4-6), whereas secreted OPG, a member of the TNF receptor superfamily, acts as a soluble decoy receptor by binding RANKL and preventing RANKL-induced osteoclastic bone resorption (7).

RANKL mRNA is expressed not only in bone tissue, but also in bone marrow and lymphatic tissue. Its main role in bone is to stimulate osteoclast differentiation and activation. RANKL mRNA and macrophage colony-stimulating factor (M-CSF) are the only two factors required for the completion of the entire osteoclast maturation cycle from their immature precursors (4).

Normal triiodothyronine (T3) concentrations are essential for normal bone metabolism. Hyperthyroidism may result in a deleterious effect on bone, leading to secondary osteoporosis. Thyroid hormones seem to affect bone by acting either directly on osteoclasts or via osteoblasts, stimulating bone resorption (5).

The best known mechanism for the activation of osteoclast differentiation, demonstrated in vitro, is that in which T3 stimulates osteoclastic bone resorption only in the presence of osteoblast co-cultures, indicating that osteoblasts are the primary T3 target (8). In this case, osteoclastic differentiation would probably be mediated by RANKL, and T3 would always stimulate osteoclastic bone resorption in the presence of osteoblasts, but never in their absence (9).

Given that thyroid hormone receptors (TRs) are present in osteoclast precursor cells, there could be another osteoclastic differentiation pathway. Thus, T3 would stimulate osteoclastic differentiation by directly activating osteoclast precursors in the absence of osteoblastic lineage cells being, therefore, independent from RANKL activation.

Miura e cols. (10), 2002 observed that T3 $\left(10^{-8}-\right.$ $\left.10^{-5} \mathrm{M}\right)$ induced RANKL mRNA expression, and that RANKL expression was significantly increased when T3 was used in the presence of $1,25(\mathrm{OH})_{2} \mathrm{D}_{3}$ (dihydroxyvitamin $\mathrm{D}_{3}$ ) in primary osteoblastic cell cultures. In addition, osteoprotegerin (OPG) expression decreased after treatment with T3 associated with $1,25(\mathrm{OH})_{2} \mathrm{D}_{3}$, enhancing the RANKL/OPG ratio. Thus, they demonstrated that thyroid hormones induced RANKL mRNA expression and enhanced $1,25(\mathrm{OH})_{2} \mathrm{D}_{3}$-induced osteoclast formation

On the other hand, Kanatani e cols. (11), 2004, studying the mechanisms through which $\mathrm{T} 3$ stimulates osteoclast differentiation in both the presence and absence of osteoblastic cells, found that T3 (1pM-100nM) did not affect RANKL mRNA expression, but stimulated OPG expression, suggesting that the stimulatory effect of T3 on osteoclast differentiation was not mediated by the RANKL/OPG system.

Given that the available data on the influence of T3 on RANKL expression are scarce and conflicting, our purpose was to check whether T3 can induce RANKL mRNA expression in rat osteoblastic cells (ROS $17 / 2.8)$.

\section{MATERIALS AND METHODS}

\section{Materials}

HAM's F-12 culture medium, Dulbecco's phosphate buffered saline (FBS), tripsin and EDTA were obtained from GIBCO BRL, Grand Island, NY., USA; TRIzol reagent, SuperScript ${ }^{\mathrm{TM}}$ First-Strand Synthesis System for RT-PCR, fetal bovine serum (FBS), and primers from Invitrogen Corp., Carlsbad, CA, USA; $17 \beta$-estradiol $\left(\mathrm{E}_{2}\right), 1-3,5,3$ 'triiodothyronine $(\mathrm{T} 3)$ from Sigma Chemical Co., St. Louis, MO., USA, and cell proliferation reagent WST-1 from Roche.

\section{Methods}

\section{Cell Culture}

ROS $17 / 2.8$ cells, kindly provided by Dr. Cecília H.A. Gouveia (São Paulo University Biomedical Science Institute), were kept in HAM's F-12, antibiotic antimycotic, medium containing penicillin, streptomycin, and amphotericin (GIBCO BRL, Grand Island, NY., USA BRL) supplemented with $10 \% \mathrm{FBS}$ in a humidified atmosphere at $37^{\circ} \mathrm{C}$ and $5 \%(\mathrm{v} / \mathrm{v}) \mathrm{CO}_{2}$. For hormone treatment, cells were grown in a serum-free medium for 48 hours. The cell lineage used has thyroid hormone receptors (TR). 


\section{Treatment Groups}

T3 was added to the medium at concentrations of $10^{-8} \mathrm{M}, 10^{-9} \mathrm{M}$, and $10^{-10} \mathrm{M}$. A control group without $\mathrm{T} 3$ treatment was also used.

\section{Hormone Stimulation}

ROS 17/2.8 cells were plated in $100 \mathrm{~mm}$ dishes (Nalgen Nunc International, Rochester, NY, USA). Upon reaching semi-confluence, cells were washed with Dulbecco's PBS and T3 was added to HAM's F-12 medium without FBS at the above concentrations. After 72 -hour incubation with hormone medium, functional activity tests were performed. Treatments with each hormone concentration were repeated five times $(n=5)$.

\section{RNA extraction and Semiquantitative RT-PCR}

RNA was extracted from cells cultures using $1 \mathrm{ml}$ TRIzol. Total RNA was analyzed by agarose gel electrophoresis, quantified by spectrophotometry at $260 \mathrm{~nm}$, and stored at $-70^{\circ} \mathrm{C} ; 1 \mu \mathrm{g}$ RNA was reverse transcribed using random hexamer priming (SuperScript ${ }^{\mathrm{TM}}$ FirstStrand Synthesis System for RT-PCR).

Complementary DNAs (DNAs) were amplified by RT-PCR, using primers for rat RANKL and cyclophylin as an internal control (Table 1).

Table 1. Primer of rat Rankl and Cyclophylin.

\begin{tabular}{|c|c|c|}
\hline RANKL rat & $\begin{array}{l}\text { sense: } 5^{\circ} \text {-CCAGCATCAAAATCCCAAGT-3` } \\
\text { antisense: } \\
\text { 5'-TGAAAGCCCCAAAGTACGTC-3` }^{\circ}\end{array}$ & product:200pb \\
\hline Cyclophylin rat & $\begin{array}{l}\text { sense: } 5^{\circ} \text {-ACGCCGCTGTCTCTTTTC-3' } \\
\text { antisense: } 5^{\prime} \text {-TGCCTCTTCACCTCC-3' }\end{array}$ & product:440pb \\
\hline
\end{tabular}

Thirty cycles and $59.5^{\circ} \mathrm{C}$ were used for semiquantitive RT-PCR reaction for the RANKL and cyclophylin genes. PCR reaction products were separated in $1 \%$ agarose gel and quantified with Labworks Analyses Software ${ }^{\circledR}$ (UVP). Results were expressed as means between RANKL and cyclophylin (control) optical density.

Statistical analysis was done by non-parametric analysis of variance, complemented by the multiple comparisons test.

This research project was approved by the Research Ethics Committee of Botucatu School of Medicine, São Paulo State University - Unesp.

\section{RESULTS}

\section{Expression of RANKL cellular resorption marker}

RANKL expression in cells treated with $\mathrm{T} 3$ at $10^{-8} \mathrm{M}$, $10^{-9} \mathrm{M}, 10^{-10} \mathrm{M}$ concentrations, and in the control group were $0.049 \pm 0.016,0.073 \pm 0.022,0.110 \pm$ 0.061 , and $0.089 \pm 0.064$, respectively. There was no significant difference between T3 concentrations $(\mathrm{p}>0.05)$ (Figure 1).

\section{DISCUSSION}

One of the possible differentiation pathways of osteoclast precursor cells into mature osteoclasts is via mediation of RANKL/RANK signal transduction. Takayanagi et al. (6), 2002, showed that RANKL produced in osteoblasts binds to RANK, which is found in pre-osteoclasts, and thus promote their differentiation.

Triiodothyronine stimulates osteoblastic activity both directly and indirectly via several growth factors and cytokines (12). In contrast, osteoclasts only reabsorb bone in the presence of osteoblastic cells (4, $8)$. Therefore, the osteoclast differentiation activation process is probably dependent on an osteoblastrelated factor.

Although thyroid hormones increase the activity of both osteoclasts and osteoblasts in vivo and in vitro, little is known about their effects on target genes (13).

Miura e cols. (10), 2002, using Northern Blot analysis to measure mRNA expression, showed that T3 $\left(10^{-8}\right.$ $\left.-10^{-5} \mathrm{M}\right)$, at concentrations greater than those used in our study induced RANKL expression in rat primary osteoblastic cells.

In another similar study, Kanatani e cols. (11), 2004, using semiquantitative RT-PCR, demonstrated that T3 (lpM-100nM) stimulated osteoclast formation dosedependently, and increased OPG but not RANKL expression, suggesting that the stimulatory effect of T3 on osteoclast formation was not mediated by the RANKL/ OPG system.

Our findings show that $\mathrm{T} 3$ at concentrations of $10^{-8}, 10^{-9}$, and $10^{-10} \mathrm{M}$ did not enhance RANKL expression in ROS 17/2.8 lineage osteoblastic cells (Figure $1 B)$, suggesting that factors other than RANKL are in- 


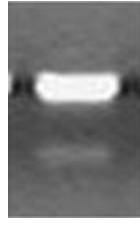

a

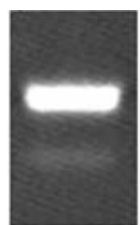

C

* Cyclophylin (440 bp)

** Rankl

(200 bp)

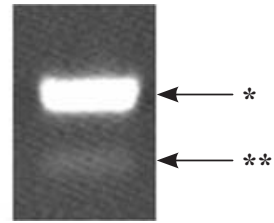

b

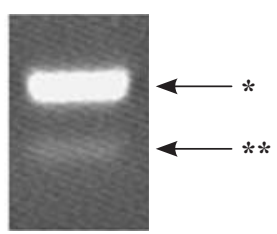

d

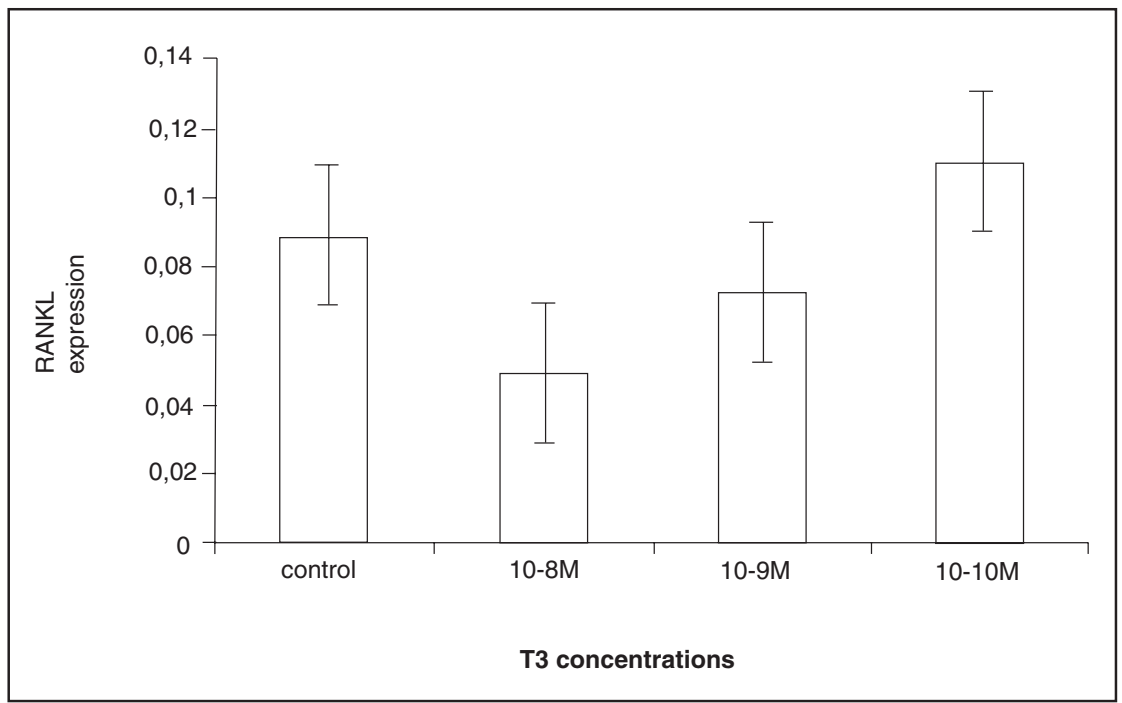

Figure 1. A) RANKL mRNA (200 pb) expression in ROS $17 / 2.8$ cells submitted to different T3 concentrations ( $\mathrm{a}=$ without T3, b= $10-8 \mathrm{M}, \mathrm{c}=10-9 \mathrm{M}$ e $\mathrm{d}=10-10 \mathrm{M})$, and analysed by semiquantative RT-PCR (30 cycles, $59.5^{\circ} \mathrm{C}$ ). Cyclophylin (440 pb) was used as reaction control. B) Mean and total half-width of the mean between RANKL mRNA expression and cyclophylin in the control group (no treatment) and the different T3 concentrations. There was no significant difference between groups (p>0.05). Statistical analysis was done by non-parametric analysis of variance, complemented by the multiple comparisons test

volved in the activation of pre-osteoclastic cell differentiation.

Transcription factor PU.1, which is expressed in osteoclast precursor cells, is known to be required for the initial stages of osteoclast differentiation. However, other factors, such as c-Fos, NFאB, and Fra-1 (14), are also essential for the stimulation of precursor cells differentiation into mature osteoclasts.

Kanatani e cols. (11), 2004 also examined the effect of T3 on the formation of osteoclastic cells from hematopoetic cells in the absence of osteoblasts and found that T3 stimulated osteoclast formation and increased c-Fos and Fra-1 expression in precursors, indicating that differentiation was probably activated by these factors.

Several cytokines, such as TNF $\alpha$ and IL-1, are known to regulate osteoclast function and differentiation irrespective of the RANK/RANKL system (15). Tanabe e cols. (16), 2005, showed that IL- $1 \alpha$ stimulates osteoclastic cell formation by increasing M-CSF and $\mathrm{PGE}_{2}$ production.

A couple of studies $(17,18)$ have shown that the deleterious effect on bone tissue caused by hyperthyroidism might be mediated by interleukin-1, IL-6, and tumor necrosis factor (TNF).
Since T3 did not affect RANKL expression in the cells in T3 concentrations used in this study, higher hormonal concentrations and further mechanisms for the activation of osteoclast differentiation should be considered. ROS 17/2.8 cells express many factors (cFos, IL-1, M-CSF e PGE2) that may regulate osteoclast differentiation independently from the RANK/ RANKL system (14).

Further studies are necessary for the identification of the triggering mechanisms of osteoclast differentiation.

\section{ACKNOWLEDGEMENTS}

Supported by Fapesp (03/03304-9) grant. We thank Dra. Cecília H.A. Gouveia (São Paulo University Biomedical Science Institute) for ROS 17/2.8 cells.

\section{REFERENCES}

1. Rodan GA, Martin TJ. Therapeutic approaches to bone diseases. Science. 289:1508-14.

2. Klaushofer K, Peterlik M. Pathophysiology of fracture healing. Radiologe. 1994;34:709-14.

3. Li J, Sarosi I, Yan XQ, Morony S, Capparelli C, Tan HL, et al. RANK is the intrinsic hematopoietic cell surface receptor that 
controls osteoclastogenesis and regulation of bone mass and calcium metabolism. PNAS. 2000;97:1566-71.

4. Ferrer-Cañabate J, Tovar I, Martines P. Osteoprotegerina y Sistema RANKL/RANK: el futuro del metabolismo óseo. An Med Intern. 2002;19:385-8.

5. Lakatos P. Thyroid hormones: benefical or deleterious for bone? Calcif Tissue Int. 2003;73:205-9.

6. Takayanagi H, Kim S, Marsuo K, Suzuki H, Suzuki T, Sato K, et al. Rankl maintains bone homeostasis through c-Fos-dependent induction of interferon- $\beta$. Nature. 2002;416:744-9.

7. Simonet WS, Lacey DL, Dunstan CR, Kelley M, Chang MS, Lúthy $R$, et al. Osteoprotegerin: a novel secreted protein involved in the regulation of bone density. Cell. 1997;99:309-19.

8. Bassett JHD, Williams GR. The molecular actions of thyroid hormone in bone. Trends Endocrinol Metab. 2003;14:256-64.

9. Brito JM, Fenton AJ, Holloway WR, Nicholson GC. Osteoblasts mediate thyroid hormone stimulation of osteoclastic bone resorption. Endocrinology. 1994;134:196-76.

10. Miura M, Tanaka K, Komatsu Y, Suda M, Yasoda A, Sakuma Y, et al. A novel interaction between thyroid hormones and $1,25(\mathrm{OH}) 2 \mathrm{D} 3$ in osteoclast formation. Biochem Biophys Res Commun. 2002;291:987-94.

11. Kanatani M, Sugimoto T, Sowa $Y$, Kobayashi T, Kanzawa M, Chihara K. Thyroid hormone stimulates osteoclast differentiation by a mechanism independent of RANKL-RANK interaction. J Cell Physiol. 2004;201:17-25.

12. Yen PM. Physiological and Molecular Basis of Thyroid Hormone Action. Physiol Rev. 2001;81:1097-142.

13. Mizukami J, Takaesu G, Akatsuka H, Sakurai H, Ninomiya-Tsuji J, Matsumoto K, et al. Receptor activator of NF-KB ligand
(RANKL) activates TAK1 mitogen-activated protein kinase kinase kinase through a signaling complex conteining RANK, TAB2, and TRAF6. Mol Cell Biol. 2002;22:992-1000.

14. Owens JM, Marsuo K, Nicholson GC, Wagner EF, Chambers TJ. Fra-1 potentiates osteoclastic differentiation in osteoclastmacrophage precursor cell-lines. J Cell Physiol. 1999;179: 170-8.

15. Azuma Y, Kaji K, Karagiri R, Takeshira S, Kudo A. Tumor necrosis factor- $\alpha$ induces differentiation of and bone resorption by osteoclasts. J Biol Chem. 2000;275:4858-64.

16. Tanabe N, Maeno M, Suzuki N, Fujisaki K, Tanaka H, Ogiso B, et al. IL-1 alpha stimulates the formation of osteoclast-like cells by increasing M-CSF and PGE2 production and decreasing OPG production by osteoblasts. Life Sci. 2005;77:615-26.

17. Simsek G, Karter Y, Aydin S, Uzum H. Osteoporotic cytokines and bone metabolism on rats with induced hyperthyroidism: changes as a result so reversal to euthyroidism. Chin J Physiol. 2003;46:181-6.

18. Kim CH, Kim HK, Shong YK, Lee KU, Kim GS. Thyroid hormone stimulates basal and interleukin (IL)-1-induced IL-6 production in human bone marrow stromal cells: a possible mediator of thyroid hormone-induced bone loss. J Endocrinol. 1999;160:97-102.

\section{Address for correspondence:}

Patrícia P. Saraiva

Rua Dr. Alípio dos Santos, 12-18, ap. 51, Jardim Panorama, 17011-136 - Bauru - SP, Brazil

E-mail: saraivapat@yahoo.com.br 